\title{
hhni \begin{tabular}{|l} 
Howard Hughes \\
Medical Hustete
\end{tabular}
}

Published as: Cell. 1991 June 28; 65(7): 1255-1266.

\section{Direct Repeats as Selective Response Elements for the Thyroid Hormone, Retinoic Acid, and Vitamin $\mathrm{D}_{3}$ Receptors}

\author{
Kazuhiko Umesono, Kevin K. Murakami, Catherine C. Thompson, and Ronald M. Evans \\ Gene Expression Laboratory, Howard Hughes Medical Institute, The Salk Institute for Biological \\ Studies, P.O. Box 85800, San Diego, California 92186-5800
}

\section{Summary}

We report here the identification of thyroid hormone response elements (TREs) that consist of a direct repeat, not a palindrome, of the half-sites. Unlike palindromic TREs, direct repeat TREs do not confer a retinoic acid response. The tandem TRE can be converted into a retinoic acid response element by increaslng the spacing between the half-sites by 1 nucleotide, and the resulting retinoic acid response element is no longer a TRE. Decreasing the half-site spacing by 1 nucleotide converts the TRE to a vitamin $\mathrm{D}_{3}$ response element, while eliminating response to $\mathrm{T}_{3}$. These results correlate well with DNA-binding affinities of the thyroid hormone, retinoic acid, and vitamin $\mathrm{D}_{3}$ receptors. This study points to the general importance of tandem repeat hormone response elements and suggests a simple physiologic code exists in which half-site spacing plays a critical role in achieving selective hormonal response.

\section{Introduction}

Steroid and thyroid hormones, as well as active metabolites of vitamins A (retinoic acid or $\mathrm{RA})$ and 1,25dihydroxycholecalciferol $\left(\mathrm{D}_{3}\right)$ contribute to vertebrate development and homeostasis by sewing as biological signals to control cell growth and differentiation. Upon binding ligand, intra-cellular receptors for these hormones act as dimeric transcription factors to activate or repress expression of nuclear target genes by binding to specific DNA sequences termed hormone response elements (HREs) (Yamamoto, 1985; Evans, 1988; Green and Chambon, 1988; Beato, 1989; Weinberger and Bradley, 1990). Cloning of receptor cDNAs and subsequent structure-function analyses have revealed a modular structure common to the proteins, which defines the steroid/thyroid hormone receptor superfamily (Evans, 1988). This hormone-receptor system provides us with a simple means to characterize genetic networks underlying cell fate and physiology. ToJvard this end, a central concern is to understand the molecular mechanism by which the receptors recognize and selectively activate target HREs.

Comparison of HREs for the glucocorticoid receptor (GR), estrogen receptor (ER), and thyroid hormone receptor (TR) points to a palindromic feature consisting of an inverted repeat of half-sites separated by a spacer of 3 or 0 nucleotides (Klock et al., 1987; Martinez et al., 1987; Glass et al., 1988). The DNA-binding domain of the receptors mediates specific recognition of the HREs and includes a cysteine-rich cluster that comprises two zinc fingerlike structures (Hollenberg and Evans, 1988; Green and Chambon, 1987; Severne et al., 1988; Freedman et al., 1988; Schena et al., 1989; Archer et al., 1990). Mutational studies of 
the zinc fingers have localized distinct regions determining sequence and spacing recognition. Three amino acids in the stem of the first finger (the P box) are critical to specify the half-site sequence, while 5 amino acids in the second finger (the D box) can alter selection pattern of the half-site spacing (Umesono and Evans, 1989; Mader et al., 1989; Danielsen et al., 1989). Nuclear magnetic resonance spectroscopy of the GR and ER DNAbinding domain polypeptides supports a model in which an a helix including the $\mathrm{P}$ box contacts the major groove of the DNA double helix, and the D box stands as a potential interface of receptor dimerization within the DNA-binding domain (Hräd et al., 1990; Schwabe et al., 1990).

These observations have led to the classification of all the receptors and related proteins into either the GR or ER/TR subfamily, based on the P box sequence (Umesono and Evans, 1989; Mader et al., 1989; Danielsen et al., 1989). The GR subfamily includes glucocorticoid, mineral-ocorticoid, androgen, and progesterone receptors. These recognize common HREs consisting of an inverted repeat of TGTTCT half-sites known as glucocorticoid response elements (GREs). All the other receptors, including the ER, two isoforms of the TRs, three isoforms of the human RA receptors (RARs) (Giguére et al., 1987; Petkovich et al., 1987; Brand et al., 1988; Benbrook et al., 1988; Krust et al., 1989; Ishikawa et al., 1990), the retinoid X receptors (Mangelsdorf et al., 1990), and the human vitamin $\mathrm{D}_{3}$ receptor (VDR) (Baker et al., 1988), belong to the ERilR subfamily.

On the basis of its distinct $\mathrm{P}$ box, the members of the ER/lR class display cross-recognition of the palindromic HREs consisting of a half-site, TGACCT (referred to hereafter in its antisense as AGGTCA), or a closely related sequence. The estrogen response element from the vitellogenin gene is recognized by the ER, TRs, and RARs (Glass et al., 1988; Brent et al., 1989a; de Verneuil and Metzger, 1990). A palindromic thyroid hormone response element (TREp; Glass et al., 1988) also serves as an efficient RA response element (RARE) for both the RARs and retinoid X receptors (Umesono et al., 1988; Ishikawa et al., 1990; Mangelsdorf et al., 1990; Graupner et al., 1989; de Verneuil and Metzger, 1990). An inverted repeat from the human osteocalcin gene is capable of mediating both vitamin DS and RA response (Schüle et al., 1990).

In contrast to these permissive properties, we show that the TRE from the rat cardiac myosin heavy chain (MHC) a subunit gene promoter (Izumo and Mahdavi, 1988) is not permissive for an RA or vitamin $\mathrm{D}_{3}$ responsiveness. While investigating its selectivity we found the expected AGGTCA-related half-sites, but in tandem rather than palin dromic arrays. Subsequent analyses uncovered that direct repeat HREs can mediate selective binding and response to the TR, RAR, and VDR. Mutations that alter the distance between the half-sites interconvert receptor specificity. These studies provide evidence for an underlying physiologic code built into DNA, which exploits uniquely spaced direct repeats of AGGTCA (or closely related sequences) to achieve specificity. Accordingly, spacers of 3, 4, and 5 nucleotides encode response to vitamin $\mathrm{D}_{3}, 3,5,3$ '-triiodothyronine $\left(\mathrm{T}_{3}\right)$, and RA, respectively. This rule applies to most of the natural HREs so far identified for these hormones. Our results suggest a simple relationship between the receptors and their binding sites and provide a correspondingly simple means to evolve new regulatory networks. 


\section{Results}

\section{Molecular Organization of the MHC TRE}

Previously we have shown that a palindromic TRE (TREp) mediates both $\mathrm{T}_{3}$ and RA response, leading to the suggestion that the TR and RAR may regulate overlapping sets of genes (Umesono et al., 1988). To test whether coregulation is a general feature of TREs, the properties of the $\mathrm{T}_{3}$ sensitive MHC gene promoter were examined. Accordingly, a reporter plasmid covering a $90 \mathrm{bp}$ upstream segment of the MHC a gene promoter (paTRE.AlOCAT; Izumo and Mahdavi, 1988) was cotransfected into CV-1 cells together with expression plasmids for the human RAR $\alpha,-\beta$, or $-\gamma$ (Giguére et al., 1987; Ishikawa et al., 1990) or the human TR $\beta$ (Thompson and Evans, 1989). In absence of the receptor expression plasmids, no stimulation of the CAT enzyme activity was observed by RA or TB (Figure 1). Expression of TR8, however, conferred asignificant $\mathrm{T}_{3}$ response, consistent with previous results employing the rat TRa (Izumo and Mahdavi, 1988). On the other hand, production of any one of three isoforms of the RARs failed to promote an RA response, although similar CAT reporter constructs encoding TREp are responsive to both TRs and RARs (see below).

To understand the molecular basis of this phenotypic difference between the TREp and the MHC TRE, a set of CAT reporters based on a minimal SV40 early promoter ( $\triangle \mathrm{SV}$-CAT) was prepared. In good agreement with Glass et al. (1989) cotransfection experiments with the TR8 expression vector demonstrated that promoters harboring either the TREp or the wild-type MHC sequence (MHC-L) are responsive to $\mathrm{T}_{3}$ (Figure 2a). Because the MHC-L resembles the rat growth hormone (rGH) TRE and the TREp (Izumo and Mahdavi, 1988;

Glass et al., 1989), the actual response element was proposed to consist of a partial palindrome of AGGTCA (Figure 2a). However, in testing this proposal a restricted region corresponding to the predicted palindrome (MHC-S reporter) failed to confer $\mathrm{T}_{3}$ responsiveness. In contrast, a segment of the MHC sequence (MHC-D) including an adjacent sequence resulted in a recovery of the full response, delineating a minimal boundary for the MHC TRE. An examination of this sequence fails to reveal a palindrome but instead identifies a direct (i.e., tandem) repeat of the hexamers AGGTGA and AGGACA.

While each individual half-site resembles the AGGTCA motif in TREp, their orientation in the MHC TRE is distinct. The ability of this element to respond to $T_{3}$ and its failure to respond to RA led us to explore the properties of the sequence in more detail. MHC-N encodes a 23 nucleotide core of the wild-type sequence. Ml and M3 contain specific nucleotide substitutions in the presumed direct repeat motif, while the M2 mutant carries those in the presumed palindrome (Figure $2 b$ ). Using COS cell extracts prepared in the presence or absence of the TR $\beta$ expression plasmid, we were able to detect specific binding of the TR8 protein to the ${ }^{32} \mathrm{P}$-labeled MHC-N oligonucleotides by a gel retardation assay (Figure 3). As a competitor, a 50-fold excess of unlabeled oligonucleotides was added to the binding reactions; both MHC-N and M2 competed, but Ml and M3 did not. This clearly demonstrates that the two G residues in both AGGTGA and AGGACA are necessary to constitute the TR $\beta$-binding site. The central 3 nucleotides AGG (that are part of the putative 
palindrome) are changeable without a significant impact on the receptor binding. This is consistent also with binding data obtained by an avidinbiotin DNA-binding assay and a footprinting pattern on the human MHC a gene promoter with the TRs (Flink and Morkin, 1990). As expected, cotransfection assays with each construct reveal that both Ml and M3 are completely silent to $T_{3}$, whereas the $M 2$ reporter retains $a T_{3}$ response, though impaired (Figure 2b). These observations support the proposal that the MHC TRE is not palindromic, but consists of a direct repeat of AGGTCA-like half-sites separated by 4 nucleotides.

\section{Direct Repeat TREs In T3-Responsive Genes}

The results with the MHC TRE led us to reexamine other previously characterized TREs. In a recent report by Petty et al. (1990) a short 20 bp DNA segment found in the $T_{3}$-responsive malic enzyme gene promoter was footprinted by the TR. When this sequence is placed in the minimal SV40 promoter it confers $\mathrm{T}_{3}$ responsiveness and, based on the above model, contains a direct repeat motif (Figure 2c). Similarly, Sap et al. (1989) identified a TRE in the murine Moloney leukemia virus (MLV) long terminal repeat (LTR) by both receptor binding and in vivo function (Figure 2c). Again, when placed into the SV40 reporter it confers $\mathrm{T}_{3}$ inducibility. Based on the MHC model, a direct repeat of the AGGTCA-like sequence can be identified in these sequences (Figure 2c). In contrast, an rGH gene sequence proposed by Brent et al. (1989b) as a candidate TRE fails to confer inducibility to the SV40 reporter (Figure 2c). However, as shown below, this sequence fails to interact with the TR in vitro and, thus, may not be a bona fide response element.

\section{TR/RAR Specificity}

While both the TRs and FtARs are able to bind palindromic TREs (Umesono et al., 1988; Glass et al., 1988; Graupner et al., 1989), the direct repeat TRE is TR specific. To understand the molecular nature of this restriction, the structure of previously characterized natural RAREs was reevaluated. Recently, one such sequence was identified in the promoter region of the mouse (Sucov et al., 1990) and human RAR $\beta$ genes (de The et al., 1990; Hoffmann et al., 1990). Interestingly, this RARE (designated $\beta R A R E$ ) is composed of a direct repeat motif and is selectively activated by the RAR but not the TR (Sucov et al., 1990; Hoffmann et al., 1990). To understand better the basis of exclusive recognition and selective response of the direct repeat TRE and RARE motifs, a series of comparative in vitro DNA-binding and functional assays was conducted.

The oligonucleotides listed in Figure 2 were used as a probe to test specific DNA binding of the RAR $a$ and TR $\beta$ in a gel retardation assay (Figure 4). On the $\beta$ RARE, a faint background binding activity was detected in the mock-transfected COS cell extract, consistent with previous results (Sucov et al., 1990). The TR $\beta$ extract contained a weak yet detectable binding activity over the background; however, the signal obtained with the RARa extract was dramatically enhanced. In addition to the MHC TRE, the malic enzyme TRE and MLV LTR TRE are all high affinity TR $\beta$-binding sites consistent with the previous observations(Glass et al., 1989; Sap et al., 1989; Petty et al., 1990; Flink and Morkin, 1990). On the other hand, TR $\beta$ binds very poorly to the rGH21 probe, which as described above also fails to confer $\mathrm{T}_{3}$-dependent transactivation in transfection experiments (Figure 2c). Finally, no appreciable binding of the RARa protein was seen with any of these TREs. In 
each case the results obtained from in vivo trans-activation and in vitro DNA binding are consistent. Thus, these tandem HREs possess intrinsic differences to impart selective TR- or RAR-specific binding and activation and virtually eliminate the possibility of hormonal cross-talk. The most obvious intrinsic differences between the TREs and the $\beta$ RARE could be either half-site spacing, primary sequence, or both (Figure 2). These possibilities can be tested by using mutations to convert TREs to RAREs and reciprocally RAREs to TREs.

\section{HRE Conversion}

Starting from the MHC TRE (MHC-N), a set of oligonucleotides (Figure 5a) was designed to introduce variations in the half-site spacing $(\mathrm{MHC}+\mathrm{l})$, the half-site sequence $(\mathrm{MHC}-\mathrm{T})$, or both (MHC-R). Parallel cotransfections with expression plasmids for TR $\beta$ or RARa were performed in $\mathrm{CV}-1$ cells along with the $\triangle \mathrm{SV}$-CAT reporter containing a single copy of the variant HRE (Figure 5b). Using the control palindromic TREp reporter, TR $\beta$ and RARa elicited a 14- and O-fold induction, respectively, while the MHC-N conferred $\mathrm{T}_{3}$ but not RA response. By increasing the spacing by 1 nucleotide, the $\mathrm{T}_{3}$ response decreased from lo-fold to less than e-fold, and conversely conferred a modest but significant induction by RA (4fold). In MHC-T the AGG $\underline{A C A}$ half-site was corrected to AGGTCA, resulting in better $\mathrm{T}_{3}$ response than the wild type while producing only a marginal RA response. In contrast, increasing the half-site spacing of MHC-T by 1 nucleotide to MHC-R generated an efficient RARE (7.4-fold), while reciprocally blunting $\mathrm{T}_{3}$ responsiveness. The position of the nucleotide insertion within the spacer is flexible; the phenotype of another mutant carrying the MHC-T mutation together with an additional G in the middle of the spacer (CAGG to CAGGG) is identical to that of the MHC-R (data not shown). Thus, half-site spacing seems to be a determinative parameter since a single nucleotide insertion (MHC-T to MHC-R) is sufficient to interconvert a TRE to an RARE.

Using the gel mobility shift assay, we also tested the DNA-binding capacity of extracts from COS cells expressing TR $\beta$ and RARa to these sequences. Figure 8a shows the pattern of TR $\beta$ binding to a ${ }^{32} \mathrm{P}$-labeled MHC-N probe following competition with the indicated oligonucleotides. The positive TREs (TREp, MHC-N, and MHC-T) showed efficient competition with MHC-T notably better than the wild type. In contrast, the RAREs (MHC +1, MHC-R, and $\beta$ RARE) were poor competitors. This pattern is consistent with that of the in vivo activation (Figure 5b). A reciprocal pattern was obtained when the same oligonucleotides were used to compete RARa binding to the ${ }^{32} \mathrm{P}$-labeled 8RARE (Figure 5b). Thus, efficient RAREs(pRARE, TREp, and MHC-R) are all effective competitors, while MHC TRE fails to compete at all. Furthermore, MHC-T, which differs by only 1 nucleotide from MHC-R, also fails to compete efficiently. This provides a striking example of the half-site spacing in generating a functional response element. The comparable binding affinity of the MHC-R to that of TREp, together with much weaker affinity of MHC+l and MHC-T, correlates well with the results from the transfection assays (Figure 5b).

The parallels between in vivo transactivation and in vitro DNA-binding patterns by two distinct receptors strongly support the conclusion that the TR binds to an AGGTCA-like direct repeat with a 4 nucleotide spacer, while the RAR recognizes a similar motif but with a spacing of 5 nucleotides. 


\section{Specific HREs for TR, RAR, and VDR}

Recent characterization of a vitamin $\mathrm{D}_{3}$ response element (VDRE) found in the ratosteocalcin (rOST) gene promoter revealed the presence of three AGGTCA-related sequences in close proximity (5'-TGGGTGAATGAGGACATTACTGACCG-3' Demay et al., 1990; Markose et al., 1990). The 5'portion of the rOST VDRE contains a tandem array of GGGTGA and AGGACA and is similar to the MHC TRE (Figure 2), although this TRE itself does not confer vitamin $\mathrm{D}_{3}$ response (data not shown). This led us to speculate that the important role of the half-site spacing for TR and RAR selectivity might extend to the VDRE, in which half-sites are spaced by 3 nucleotides.

Accordingly, a nested set of synthetic HREs was designed by making a direct repeat of AGGTCA with a spacer size variation of 3, 4, or 5 residues (Figure 7a). DR-4 encodes two copies of AGGTCA in direct repeat separated by4 nucleotides, and in principle should be aTRE. A single nucleotide insertion created DR-5 with a 5 nucleotide spacer for an RARE. Similarly, a 1 nucleotide deletion from the spacer gave rise to DR-3, a VDRE candidate. We also synthesized oligonucleotides that share identical structures to the DR series, but encode a GRE half-site (AGAACA) instead of AGGTCA, as a further control for sequence specificity (GDR series; Figure 7a).

The above strategies were taken to test both in vivo transactivation and in vitro DNA binding of these artificial HREs for TRP, RARa, and VDR. Transfection assays in CV-1 cells revealed that DR-3 is indeed a novel VDRE (8.3-fold; Figure 7b). As we expected, a single nucleotide insertion in the spacer from DR-3 to DR-4 mutually interconverts the vitamin $\mathrm{D}_{3}$ and $\mathrm{T}_{3}$ responses (22-fold induction by $\mathrm{T}_{3}$ through DR-4; Figure $7 \mathrm{c}$ ). The half-site mutants GDR-3 and -4 are completely inactive for both the VDR and TR. While DR-5 confers the best RA response (g-fold induction), DR-3 and -4 show clear activity (Figure 7d). As shown below this is probably a consequence of overexpression of the receptor protein. All of these properties of the synthetic DR HREs can be transferred to a different basal promoter such as the herpessimplexvirus thymidine kinase gene promoter (data not shown).

When the DR reporters are transfected into RA-responsive F9 teratocarcinoma stem cells, only DR-5 serves as a functional RARE (Figure 8a). Similarly, when the same set of reporters as in Figure 5 is transfected into the F9 cells, only MHC-R (5 nucleotide spacer) and TREp are potent RAREs (Figure 8b). In contrast, its RARE antecedents (MHC-N, MHC $+\mathrm{i}$, MHC-T) are inert. Using $\beta R A R E$ as a probe, we detected a specific protein-DNA complex in extracts prepared from the F9 stem cells, which reveals a DNA-binding pattern identical to that of RARa-transfected COS cell extracts (Figure 8c). These differential transactivation and DNA-binding patterns correlated well with our hypothesis of the direct repeats being selective HREs.

Finally, in vitro DNA-binding assays were carried out with COS cell extracts containing one of these receptor proteins. With DR-3, DR-4, and DR-5 as a labeled probe, a specific protein-DNA complex was observed, which is respectively dependent on the expression of the VDR, TR $\beta$, and RARa protein in the cell (Figure 9). These studies parallel the transactivation experiments and support the idea that the DR-3, -4 , and -5 sequences represent specific binding response elements for VDR, TR $\beta$, and RARa, respectively. 


\section{Discussion}

Although it seems that there must be a mechanism underlying physiologic specificity of the hormonal response, previous studies were unclear as to how this was achieved. Because nuclear receptors are sequence-specific DNA-binding proteins, it is widely, and reasonably, assumed that specificity resides in the sequence of the receptor-binding sites in target genes. To focus on this problem, we have studied the pattern of HRE-dependent transactivation achieved by the three distinct nuclear receptors, TR, RAR, and VDR. Our results demonstrate that each receptor can recognize the common consensus half-site sequence AGGTCA in the form of a direct repeat. We provide additional evidence that specificity of the hormonal response is achieved through unique spacing of the direct repeats. Together, these studies reveal an underlying physiologic code built into DNA wherein the direct repeat of AGGTCA (or related sequence; see below) separated by 3 nucleotides (DR-3) is a VDRE; by 4 nucleotides (DR-4) a TRE; and by 5 nucleotides (DR-5) an RARE (see Figure 10 for a summary). This "3-4-5" rule suggests an evolutionary association between the receptors and their binding sites. The recognition of this simple relationship provides an equally simple means to entrain new genes into a receptor-activated regulatory network, while at the same time providing the minimal amount of hormonal cross-talk.

\section{Common Recognition Mode in a Subset of Nuclear Receptors}

Several aspects of this work strengthen the relatedness of the TR, RAR, and VDR. First, they are able to bind and activate through the common half-site sequence AGGTCA. This sequence is also the binding site for the ER, but only in the form of a palindrome or inverted repeat. These studies raise the possibility that the ER might also recognize the direct motif. However, we have been unable to provide any evidence for this supposition (K. U. and R. M. E., unpublished data). Therefore, the direct repeat mode of sequence recognition may represent a distinct evolutionary branch within the nuclear receptor family. In a previous study we have predicted that all receptors would belong to either the ER/TR subfamily or to the GR subfamily based on the amino acid composition of the P box in the DNA-binding domain. We and others have provided evidence that this portion of the first zinc finger specifies the target half-site sequence.

The results in this study support the $\mathrm{P}$ box hypothesis, while at the same time presenting a novel means to achieve selective sequence recognition by the utilization of the direct repeat. Perhaps the most unusual aspect of this recognition is that the physical relationship of the DNA-binding domain of the receptor dimer undergoes a $180^{\circ}$ rotational inversion between the inverted and direct repeat. In addition, both the TR and RAR recognize a common palindromic response element (i.e., TREp). How a single transcription factor can recognize both direct and inverted binding sites is unclear. However, the inversion of the half-site implies that the entire relative orientations of the intact receptors are also altered. Recent reports on heterodimer formation among receptor proteins and on nuclear proteins that can modulate the DNA-binding activity of the TR, RAR, and/or VDR indicate that these modulatory interactions may play certain roles in selective recognition of the palindromic and direct repeat HREs to activate gene expression (Glass et al., 1989, 1990; Forman et al., 
1989; Murray and Towle, 1989; Burnside et al., 1990; Lazar and Berrodin, 1990; Liao et al., 1990).

\section{HRE Diversity}

TR-Binding Sites-The characterization of the palindromic TRE (Glass et al., 1988) reinforced the long-accepted role of inverted repeats as mediators of the action of nuclear receptors. The demonstration that the TREp is also an effective RARE (Umesono et al., 1988) strengthened this idea and suggested extensive overlap between RA- and $T_{3^{-}}$ responsive genes. This study leads to a reevaluation of the generality of these conclusions. In the case of the MHC TRE it was initially suggested that the response element was an inverted repeat (Izumo and Mahdavi, 1988; Glass et al., 1989). However, that hypothesis is not supported by the work in this paper, in which we provide evidence that the relevant response element is a direct repeat separated by 4 nucleotides. While a direct repeat motif in the human MHC TRE was also pointed out by Flink and Morkin (1990), their assignment of the half-sites is different from ours. The TREs in the MLV LTR and in the promoter of the gene encoding malic enzyme follow our rule quite well (Figure 10).

After this work was completed, similar mutational analyses of the malic enzyme gene TRE were reported (Desvergne et al., 1991). Their results strongly support our model that the direct repeat formed by the hexamer half-sites is essential to constitute the functional TRE. An exception to our rule is the TRE in the rGH gene promoter. Studies by Glass et al. (1988) suggest that this response element would be a partial palindrome. However, extensive mutational studies of this TRE pointed to a more complicated structural feature (Brent et al., 1989a, 1989b). Involvement of a potential direct repeat in the rGH TRE as pointed by these studies was tested also in this study, but we are unable to show that this proposed direct repeat alone ( $\mathrm{rGH} 21$ ) confers hormone responsiveness to a heterologous promoter. In light of our model, this seems due to a weak affinity of the half-sequence AGGTAAA instead of AGGTㅁA for the TR protein.

Other exceptions to our rule include the estrogen response element palindrome variably conferring negative or positive $\mathrm{T}_{3}$ responsiveness depending on the individual study (Glass et al., 1988; Brent et al., 1989a; de Verneuil and Metzger, 1990; Holloway et al., 1990; our unpublished data), a reported TRE in the rGH gene intron (Sap et al., 1990), and the S14 gene TRE (Zilz et al., 1990). However, a reinterpretation of the S14 element (Howard Towle, personal communication) suggests it may conform to our model (Figure 10). Several negative TREs have been identified including the reverse palindrome in the chicken lysozyme silencer (Baniahmad et al., 1990), a GC-rich tract in the EGF receptor gene promoter (Hudson et al., 1990), and ones adjacent to or overlapping the TATA boxes in the TSHa and $-\beta$ genes and the rGH gene (Darling et al., 1989; Wondisford et al., 1989; Burnside et al., 1989; Chatterjee et al., 1989; Crone et al., 1990). At present, how these response elements contribute to positive/negative regulation versus the DR-4 positive regulatory element is unclear.

RAR-Bindlng Sites-The RAR presents the same paradox as the TR in the sense that it is capable of effectively activating through the synthetic TREp as well as the direct motifs 
(DR-5). Although the RAR recognizes the AGGTCA half-site, naturally occurring sequences include (G/A)GTTCA in the $\beta$ RARE. We propose that the 3-4-5 rule in the direct repeat HREs also applies to an RARE localized in the promoter region of the complement factor H gene (Muiioz-Canoves et al., 1990) and to one in the human alcohol dehydrogenase gene (ADH3; Duester et al., 1991), in which only one base mismatch is found from our consensus motif (Figure 10). The importance of the spacer size is further substantiated by the fact that deletion of one of the internal A residues from the spacer region in the $\beta$ RARE (which we designate $\beta$ RARE-1) silences the RA response in FQ cells (data not shown). Thus, specific HRE recognition by the RAR should be achieved by a similar mechanism employed by the TR. We note, however, that the above spacer mutant of the $\beta d A R E$ ( $\beta$ RARE-1), which follows the DR-4 motif, fails to confer efficient $T_{3}$ response. This indicates that certain half-sites may be incompatible for TR activation and reemphasizes the importance of the primary sequence in conjunction with appropriate spacing to achieve a functional response element.

A distinct structural feature in the mouse laminin Bl RARE (Vasios et al., 1989) is comparable to the rGH intron TRE, in which the AGGTCA-like motifs are widely dispersed. We note that identification of RAREs must be approached with caution since excess expression of the RARs leads to an apparent increase of transactivation through both $\mathrm{MHC}+1$ and MHC-T to overcome relatively low binding affinity. Similarly, overexpressed RARs have less specificity in discriminating the spacer size variants DR-3, DR-4, and $\beta R A R E-1$. However, under naturally occurring concentrations of the RARs, like that in FQ cells, RA response is detectable only through the high affinity binding sites(e.g., TREp, $\beta$ RARE, MHC-R, and DR-5). The inability of the laminin Bl RARE to respond to RA under these conditions (Vasios et al., 1989) may be a reflection of its low binding affinity. Interestingly, this dosedependent effect seems specific to the RARs since the TRs and VDR do not exhibit this permissive activation tendency when overexpressed.

VDR-Binding Sites-The novel VDRE identified in this study (DR-3) matches quite closely to a part of the VDR-binding site in the rat and human osteocalcin gene promoter (Demay et al., 1990; Markose et al., 1990; Ozono et al., 1991). Asecond weaker response element overlapping an adjacent AP-1-binding site has also been shown to confer a vitamin DS and RA response in the human gene (Kerner et al., 1989; Morrison et al., 1989; Schijle et al., 1990). We confirmed that both of these sequences compete for binding of the VDR protein to the DR-3 probe, although the second site is less effective. Another example of a naturally occurring VDRE was identified recently in the promoter region of the mouse Sppllosteopontin gene (Noda et al., 1990). This VDRE follows our rule well, and the half-sites are remarkably similar to those found in the $\beta$ RARE, which does not mediate vitamin D3 response (Sucov et al., 1990; see Figure 10). It is of interest to test mutants of this VDRE and $\beta R A R E$, which contain, respectively, a two base insertion and deletion in the spacer for reciprocal conversion of the hormonal response.

\section{Conclusions}

Although several reports have sporadically identified direct repeats as constituting HREs, based on our studies, we suggest that these may represent a common mode of DNA binding 
for a subset of nuclear receptors. This study also identifies an underlying relationship between response elements for the TR, RAR, and VDR in which spacing plays a critical role in achieving selective hormonal response. From a historical perspective, one division in the nuclear receptor family may have been the evolution of a protein capable of recognizing the AGGTCA direct repeat motif. As new receptors were generated, corresponding, novel genetic response networks could be created by altering the spacing requirements in the response elements without requiring a concomitant change in the primary sequence recognition capabilities of the DNA-binding domain. Thus, the use of spacing to impose selective response facilitates a simple means to create novel regulatory networks. Insertion of a single nucleotide will protract the half-site by $3.4 \AA$ and simultaneously impose a $36^{\circ}$ positive rotation. Deletion will result in a $3.4 \AA$ contraction and a negative $36^{\circ}$ twist around the double helix. How these changes promote or preclude binding and how the geometry of the bound receptor influences activity is unclear.

While the 3-4-5 rule provides an explanation for hormonal response of the VDR, TR, and RAR, it also leads to speculation that the remaining spacing options will serve as open slots for other members of the nuclear receptor family. The molecular underpinnings of this model are not yet known and will require a greater analysis of the interaction of the receptors with their cognate response elements to understand better its ultimate potential and limitations.

\section{Experimental Procedures}

\section{Plasmids}

Receptor expression plasmids used in the cotransfection assay were described previously (pRShTR $\beta$, Thompson and Evans, 1989; pRShRAR $\beta$, Giguere et al., 1987; pRShRAR $\beta$ and pRShRAR $\gamma$, Ishikawa et al., 1990; pRShVDR, Schtile et al., 1990). A basal reporter plasmid, $\Delta$ SV-CAT, was constructed by replacing the TK promoter in TK-CAT (Damm et al., 1989) with the Sphl-Hindlll fragment of the SV40 early promoter. All of the recombinant CAT reporter plasmids used in this study harbor a single copy of the indicated oligonucleotides at the unique Hindlll site upstream of the SV40 promoter. Identity of the inserted oligonucleotides was confirmed by sequencing. To improve production of receptor proteins in COS cells, a new eukaryotic expression vector, pCMX, was prepared by modifying the plasmid CDM8 (Seed, 1987). The CDM8 was cut with Mlul and Stul in order to release the DNA fragment encoding the CMVTT7 promoter, SV40 small $t$ intronl poly(A) signal, polyoma virus enhancer/origin, and SV40 enhancer/origin. The resulting fragment was ligated to a larger fragment of Pvull-digested pUCl9. An internal deletion was introduced between unique $\mathrm{BamHl}$ and Bell sites present in the CDM8 portion. The stuffer sequence flanked by Xbal sites was replaced with a synthetic polylinker coding for 5' -Kpnl/ Asp718-EcoRV-BamHI-Mscl-Nhel-J', followed by a stretch of 5'-TAGGTAGCTAG-3 ', which can function as a universal termination signal for protein translation. The coding sequence of the luciferase (de Wet et al., 1987) and human TR $\beta$, RARa, and VDR was respectively placed in the polylinker region of the pCMX, generating pCMX-LUC, pCMXhTR $\beta$. pCMX-hRARa, and pCMX-hVDR. The translation start site of the RARa was modified to ACCACC $\underline{A T G}$ by attaching the synthetic linker encoding a consensus 
translation start signal (Hollenberg and Evans, 1988). This modification resulted in a much better yield of the receptor translation as judged in the in vitro reticulocyte lysate translation system.

\section{Cotransfectlon Assay}

A monkey kidney cell line, CV-1, was kept in DMEM supplemented with $10 \%$ charcoalresin double-split calf bovine serum. Transfections were performed via the calciumphosphate precipitation method as described (Umesono and Evans, 1989) with $0.5 \mu \mathrm{g}$ of a pRS receptor expression plasmid, $1.0 \mu \mathrm{g}$ of a reporter CAT plasmid. $5 \mu \mathrm{g}$ of pRAS- $\beta$ GAL (Umesono and Evans, 1989) as an internal control, and $8.5 \mu \mathrm{g}$ of carrier plasmid pUC19. The cells were transfected for $8 \mathrm{hr}$, and after the DNA precipitates were washed, they were incubated for an additional $36 \mathrm{hr}$ with or without the ligand $\left(\mathrm{T}_{3}, 100 \mathrm{nM}\right.$; RA, $1 \mu \mathrm{M} ; 1$, 25$(\mathrm{OH})_{2}$ vitamin $\left.\mathrm{D}_{3}, 100 \mathrm{nM}\right)$. Cell extracts were prepared for $\beta \mathrm{GAL}$ and CAT assays as described (Umesono and Evans, 1989). Transfection of F9 teratocarcinoma cells was carried out with a similar method except the cells were incubated for $12 \mathrm{hr}$ in the presence of the DNA precipitates and the RA was added at $1 \mu \mathrm{M}$ for another $24 \mathrm{hr}$ before harvesting the cells. Two, 5, and $4 \mu \mathrm{g}$ of the reporter, pRAS- $\beta \mathrm{GAL}$, and pUC19 were used, respectively.

\section{DNA-Binding Assay}

COS cells were cultured in DMEM with $10 \%$ calf bovine serum and transfected by the calcium-phosphate method with $20 \mu \mathrm{g}$ of the pCMX receptor expression plasmid for $6 \mathrm{hr}$ followed by a glycerol shock. After incubating the transfected COS cells for another $48 \mathrm{hr}$, the cells were harvested to prepare extracts for the DNA-binding assay as described by Damm et al. (1989). The extracts were made In 20 mM HEPES (pH 7.4) 0.4 M KCI. 2 mM DTT, and $20 \%$ glycerol. A similar method was employed to prepare a whole-cell extract from F9 stem cells. For the binding, 5 (COS) or 10 (F9) $\mu \mathrm{g}$ of protein was incubated first in $20 \mathrm{mM}$ HEPES, $80 \mathrm{mM}$ KCI, $1 \mathrm{mM}$ DTT, 0.1\% NP-40. $2.5 \mu \mathrm{g}$ of poly(dl-dC), and 10\% glycerol on ice for $20 \mathrm{~min}$. Cold competitor oligonucleotides. when included, were added during this preincubation period. Then $40 \mathrm{fmol}$ of ${ }^{32} \mathrm{P}$-labeled oligonucleotide $\left(1-2 \times 10^{5}\right.$ $\mathrm{cpm}$, prepared through filling-in reaction by Klenow polymerase In the presence of $\left[\mathrm{a}-{ }^{32} \mathrm{P}\right]$ $\mathrm{dCTP}$ ) probe was added to the reaction followed by incubahon at room temperature for 30 $\min$. The receptor-DNA complexes were resolved by electrophoresis through a $5 \%$ polyacrylamide gel containing $5 \%$ glycerol at $6 \mathrm{~V} / \mathrm{cm}$ at room temperature. Under the condition employed, inclusion of the ligand did not alter the DNA-binding pattern of the receptor proteins.

\section{Acknowledgments}

We thank Dr. Vijak Mahdavr for kindly providing us with paTRE.AlOCAT and Dr. J. Wesley Pike for communicating their results prior to publication. We also thank Ester Banayo for her expert technical assistance, Drs. Mike McKeown. Inder Verma, Henry Sucov, David Mangelsdorf, Tony Oro, and Steve Kliewer for discussion and critical reading of the manuscript, and Elaine Stevens for administrative assistance and help in the preparation of the manuscript. K. U. is a Research Associate and R. M. E. is an Investigator of Howard Hughes Medical Institute at the Salk Institute for Biological Studies. This work was supported by the Howard Hughes Medical Institute, the National Institutes of Health, and the Mathers Foundation.

The costs of publication of this article were defrayed in part by the payment of page charges. This article must therefore be hereby marked "advertisement" in accordance with 18 USC Section 1734 solely to indicate this fact. 


\section{References}

Archer TK, Hager GL, and Omichinski JG (1990). Sequence-specific DNA binding by glucocorticoid receptor "zinc finger peptides." Proc. Natl. Acad. Sci. USA 87, 7580-7564.

Baker AR, McDonnell DP, Hughes M, Crisp TM, Mangelsdorf DJ, Haussler MR, Pike JW, Shine J, and O'Malley BW (1988). Cloning and expression of full-length cDNA encoding human vitamin D receptor. Proc. Natl. Acad. Sci. USA 85, 3294-3298. [PubMed: 2835767]

Baniahmad A, Steiner C, Kohne AC, and Renkawitz R (1990). Modular structure of a chicken lysozyme silencer: involvement of an unusual thyroid hormone receptor binding site. Cell 67, 505514.

Beato M (1989). Gene regulation by steroid hormones. Cell 56335-344. [PubMed: 2644044]

Benbrook D, Lernhardt E, and Pfahl M (1988). A new retinoic acid receptor identified from a hepatocellular carcinoma. Nature 333,669-672. [PubMed: 2836738]

Brand N, Petkovich M, Krust A, Chambon P, deThe H. Marchio A, Tiollais P, and Dejean A (1988). Identification of asecond human retinoic acid receptor. Nature 332, 850-853. [PubMed: 2833708]

Brent GA, Harney JW, Chen Y, Warne RL, Moore DD, and Larsen PR (1989a). Mutations in the rat growth hormone promoter which increase and decrease response to thyroid hormone define a consensus thyrord hormone response element. Mol. Endocrinol 3 1996-2004. [PubMed: 2628734]

Brent GA, Larsen PR, Harney JW, Koenig AJ, and Moore DD (1989b). Functional characterization of the rat growth hormone promoter elements required for induction by thyroid hormone with and without a co-transfected 8 type thyroid hormone receptor. J. Biol. Chem 264, i78-182.

Burnside J, Darling DS.Carr FE, and Chin WW (1989). Thyroid hormone regulation of the rat glycoprotein hormone a-subunit gene promoter activity. J. Biol. Chem 264, 6886-6891. [PubMed: 2468663]

Burnside J, Darling DS. and Chin WW (1990). A nuclear factor that enhances binding of thyroid hormone receptors to thyroid response elements. J. Biol. Chem 265, 2500-2504. [PubMed: 1968058]

Chatterjee VKK, Lee J-K, Rentoumis A, and Jameson JL (1989). Negative regulation of the thyroidstimulating hormone a gene by thyroid hormone: receptor interaction adjacent to the TATA box. Proc. Natl. Acad. Sci. USA 88, 9114-9118.

Crone DE. Kim H-S, and Spindler SR (1990). $\alpha$ and $\beta$ thyroid hormone receptors bind immediately adjacent to the rat growth hormone gene TATA box in a negatively hormone-responsive region. J. Biol. Chem 265, 10851-10856. [PubMed: 2358443]

Damm K, Thompson CC, and Evans RM (1989). Protein encoded by v-erbA functions as a thyroidhormone receptor antagonist. Nature 339593-597. [PubMed: 2733791]

Danielsen M, Hinck L, and Ringold GM (1989). Two amino acids within the knuckle of the first zinc finger specify DNA response element activation by the glucocorticoid receptor. Cell 57, 11311138. [PubMed: 2500250]

Darling DS, Burnside J, and Chin WW (1989). Binding of thyroid hormone receptors to the rat thyrotropine-5 gene. Mol. Endocrinol 3, 1359-1368. [PubMed: 2608064]

Demay MB. Gerardi JM, DeLuca HF, and Kronenberg HM (1990). DNA sequences in the rat osteocalcin gene that bind the 1,25dihydroxyvitamin D3 receptor and confer responsiveness to 1,25-dihydroxyvitamin DI. Proc. Natl. Acad. Sci. USA 87, 369-373. [PubMed: 2153298]

Desvergne B, Petty KJ, and Nikodem VM (1991). Functional characterization and receptor binding studies of the malic enzyme thyroid hormone response element. J. Biol. Chem 288, 1006-1013.

de Verneuil H, and Metzger D (1990). The lack of transcriptional activation of the v-erbA oncogene is in part due to a mutation present in the DNA binding domain of the protein. Nucl. Acids Res 78, 4489-4497.

de Wet JR, Wood KV, DeLuca M, Helinski DR, and Subramani S (1987). Firefly luciferase gene: structure and expression in mammalian cells. Mol. Cell. Biol 7, 725-737. [PubMed: 3821727]

Duester G, Shean ML. McBride MS, and Stewart MJ (1991). Retinoic acid response element in the human alcohol dehydrogenase gene ADM: implications for regulation of retinoic acid synthesis. Mol. Cell. Biol 11, 1638-1646. [PubMed: 1996113] 
Evans RM (1988). The steroid and thyroid hormone receptor super-family. Science 240, 889-895. [PubMed: 3283939]

Flink IL, and Morkin E (1990). Interaction of thyroid hormone recep tors with strong and weak cisacting elements in the human a-myosin heavy chain gene promoter. J. Biol. Chem 265, 1123311237. [PubMed: 2162840]

Forman BM, Yang C, Au M, Casanova J, Ghysdael J, and Samuel H (1989). A domain containing leucine-zipper-like motifs mediate novel in vivo interactions between the thyroid hormone and retinoic acid receptors. Mol. Endocrinol 3, 1610-1626. [PubMed: 2558297]

Freedman LP, Luisi BF, Korszum ZR, Basavappa R, Sigler PB, and Yamamoto KR (1988). The function and structure of the metal coordination sites within the glucocodicoid receptor DNA binding domain. Nature 334, 543-546. [PubMed: 3043231]

Giguere V, Ong ES, Segui P, and Evans RM (1987). Identification of a receptor for the morphogen retinoic acid. Nature 330, 624-629. [PubMed: 2825036]

Glass CK, Holloway JM, Devary OV, and Rosenfeld MG (1988). The thyroid hormone receptor binds with opposite transcrip tional effects to a common sequence motif in thyroid hormone and estrogen response elements. Cell 54, 313-323. [PubMed: 3396073]

Glass CK, Lipkin SM, Devary OV, and Rosenfeld MG (1989). Positive and negative regulation of gene transcription by a retinoic acid-thyroid hormone receptor heterodimer. Cell 59, 697-708. [PubMed: 2555064]

Glass CK, Devary OV, and Rosenfeld MG (1990). Multiple cell type-specific proteins differentially regulate target gene sequence recognition by the a retinoic acid receptor. Cell 63, 729-738. [PubMed: 2171781]

Graupner G, Willis KN. Tzukerman M, Zhang X, and Pfahl M (1989). Dual regulatory role for thyroid-hormone receptors allows control of retinoic-acid receptor activity. Nature 340 653-656. [PubMed: 2549424]

Green S, and Chambon P (1987). Oestradiol induction of a glucocorticoid-responsive gene by a chimaeric receptor. Nature 325, 75-78. [PubMed: 3025750]

Green S, and Chambon P (1988). Nuclear receptors enhance our understanding of transcription regulation. Trends Genet 4, 309-314. [PubMed: 2853466]

Härd T, Kellenbach E, Boelens R, Maler BA, Dahlman K, Freedman LP, Carkitedt-Duke J, Yamamoto KR, Gustafsson J-A, and Kaptein R (1990). Solution structure of the glucocorticoid recep tor DNA-binding domain. Science 249, 157-160. [PubMed: 2115209]

Hoffmann B, Lehmann JM.Zhang X, Hermann T, Husmann M, Graupner G, and Pfahl M (1990). A retinoic acid receptor-specific element controls the retinoic acid receptor-6 promoter. Mol. Endocrinol 4, 1727-1736. [PubMed: 2177841]

Hollenberg SM, and Evans RM (1988). Multiple and cooperative rrans-activation domains of the human glucocorticoid receptor. Cell 55,899-906. [PubMed: 3191531]

Holloway JM, Glass CK, Adler S, Nelson CA, and Rosenfeld MG (1990). The C-terminal interaction domain of the thyroid hormone receptor confers the ability of the DNA site to dictate positive or negative transcriptional activity. Proc. Natl. Acad. Sci. USA 87,8160-6164. [PubMed: 2236029]

Hu MC, Sharp SB, and Davidson N (1986). The complete sequence of the mouse skeltal a-actin gene reveals several conserved and inverted repeat sequences outside of the protein-coding region. Mol. Cell. Biol 6 15-25. [PubMed: 3023820]

Hudson LG, Santon JB, Glass CK, and Gill GN (1990). Ligand-activated thyroid hormone and retinoic acid receptors inhibit growth factor receptor promoter expression. Cell 62, 1165-1175. [PubMed: 2169350]

Ishikawa T, Umesono K, Mangelsdorf DJ, Aburatani H, Stanger BZ, Shibasaki Y, Imawari M, Evans RM, and Takaku F (1990). A functional retinoic acid receptor encoded by the gene on human chromosome 12. Mol. Endocrinol 4, 837-844. [PubMed: 2172793]

Izumo S, and Mahdavi V (1986). Thyroid hormone receptor a iso-forms generated by alternative splicing differentially activate myosin HC gene expression. Nature 334, 539-542.

Kerner SA, Scott RA. and Pike JW (1989). Sequence elements in the human osteocalcin gene confer basal activation and inducible response to hormonal vitamin DB. Proc. Natl. Acad. Sci. USA 86,4455-4459. [PubMed: 2786632] 
Klock G, Strahle U, and SchOtz G (1987). Oestrogen and glucocorticoid responsive elements are closely related but distinct. Nature 329, 734-736. [PubMed: 3670376]

Krust A, Kastner P, Petkovich M, Zelent A, and Chambon P (1989). A third human retinoic acid receptor. Proc. Natl. Acad. Sci. USA 86, 5310-5314. [PubMed: 2546152]

Lazar MA, and Berrodin TJ (1990). Thyroid hormone receptors form distinct nuclear proteindependent and independent complexes with a thyroid hormone response element. Mol. Endocrinol 4, 1627-1635. [PubMed: 2280769]

Liao J, Ozone K, Sone T, McDonnell DP, and Pike JW (1990). Vitamin D receptor interaction with specific DNA requires a nuclear protein and 1,25dihydroxyvitamin 0, Proc. Natl. Acad. Sci. USA 87, 9751-9755. [PubMed: 2175914]

Mader S, Kumar V, de Verneuil H, and Chambon P (1989). Three amino acids of the oestrogen receptor are essential to its ability to distinguish an oestrogen from a glucocorticoid-responsive element. Nature 338, 271-274. [PubMed: 2922054]

Mangelsdorf DJ, Ong ES. Dyck JA, and Evans RM (1990). Nuclear receptorthat identifies a novel retinoic acid response pathway. Nature 345, 224-229. [PubMed: 2159111]

Markose ER, Stein JL, Stein GS, and Lian JB (1990). Vitamin D-mediated modifications in proteinDNA interactions at two promoter elementsoftheosteocalcin gene. Proc. Natl. Acad. Sci. USA87,1701-1705. [PubMed: 2308930]

Martinez E, Givel F, and Wahli W (1987). The estrogen-responsive element as an inducible enhancer: DNA sequence requirements and conversion to a glucocorticoid-responsive element. EMBO J 6,3719-3727. [PubMed: 3480798]

Morrison NA, Shine J. Fragonas J-C, Verkest V, McMenemy ML, and Eisman JA (1989). 1,25 dihydroxyvitamin D-responsive element and glucocorticoid repression in the osteocalcin gene. Science 246, 1158-1161. [PubMed: 2588000]

Muftoz-Canoves P, Vik DP, and Tack BF (1990). Mapping of a retinoic acid responsive element in the promoter region of the comple ment factor H gene. J. Biol. Chem 265, 20065-20068. [PubMed: 1700780]

Murray MB, and Towle HC (1989). Identification of nuclear factors that enhance binding of the thyroid hormone receptor to a thyroid hormone response element. Mol. Endocrinol 3, 1434-1442. [PubMed: 2608066]

Noda M, Vogel RL, Craig AM, Prahl J, DeLuca HF, and Denhardt DT (1990). Identification of a DNA sequence responsible for binding of the 1,25-dihydroxyvitamin $\mathrm{D}_{3}$ receptor and 1,25dihydroxyvitamin $\mathrm{D}_{3}$ enhancement of mouse secreted phosphoprotein 1 (Spp-7 or osteopontin) gene expression. Proc. Natl. Acad. Sci. USA 87, 9995-9999. [PubMed: 2175918]

Ozono K, Liao J, Kerner SA, Scott RA, and Pike JW (1991). The vitamin D-responsive element in the human osteocalcin gene. J. Biol. Chem. in press.

Petkovich M, Brand NJ, Krust A, and Chambon P (1987). A human retinoic acid receptor which belongs to the family of nuclear receptors. Nature 330, 444-450. [PubMed: 2825025]

Petty KJ, Desvergne B, Mitsuhashi T, and Nikodem VM (1990). Identification of a thyroid hormone response element in the malic enzyme gene. J. Biol. Chem 265,7395-7400. [PubMed: 2332433]

Sap J, MuriÖs A, Schmitt J, Stunnenberg H, and Vennström B (1989). Repression of transcription mediated at a thyroid hormone response element by the verb- 8 oncogene product. Nature 340 , 242-244. [PubMed: 2569164]

Sap J, Magistris L, Stunnenberg H, and Vennström B (1990). A major thyroid hormone response element in the third intron of the rat growth hormone gene. EMS0 J 9, 887-896.

Schena M, Freedman LP. and Yamamoto KR (1989). Mutations in the glucocorticoid receptor zinc finger region that distinguish inter-digitated DNA binding and transcriptional enhancement activities. Genes Dev 3, 1590-1601. [PubMed: 2515114]

Schüle R, Umesono K. Mangelsdorf DJ, Solado J, Pike JW, and Evans RM (1990). Jun-Fos and receptors for vitamins $\mathrm{A}$ and $\mathrm{D}$ recognize a common response element in the human osteocalcin gene. Cell 61 497-504. [PubMed: 2159384]

Schwabe JWR, Neuhaus D, and Rhodes D (1990). Solution structure of the DNA-binding domain of the oestrogen receptor. Nature 348, 458-461. [PubMed: 2247153] 
Seed B (1987). An LFA-3 cDNA encodes a phospholipid-linked membrane protein homologous to its receptor CD2. Nature 329, 840-842. [PubMed: 3313052]

Severne Y, Wieland S. Schaffner W, and Rusconi S (1988). Metal binding "finger" structures in the glucocorticoid receptor defined by site-directed mutagenesis. EMBO J 7, 2503-2508. [PubMed: 3191912]

Sucov HM, Murakami KK. and Evans RM (1990). Characterization of an autoregulated response element in the mouse retinoic acid receptor type 8 gene. Proc. Natl. Acad. Sci. USA 87, 53925398. [PubMed: 2164682]

Thompson CC, and Evans RM (1989). Trans-activation by thyroid hormone receptors: functional parallels with steroid hormone receptors Proc. Natl. Acad. Sci. USA 86, 3494-3498.

Trask RV, Strauss AW, and Silladello JJ (1988). Developmental regulation and tissue-specific expression of the human muscle creatine kinase gene. J. Biol. Chem 263, 17142-17149. [PubMed: 2903158]

Umesono K, and Evans RM (1989). Determinants of target gene specificity for steroid/thyroid hormone receptors. Cell 57, 1139-1146. [PubMed: 2500251]

Umesono K, Giguére V, Glass CK, Rosenfeld MG, and Evans RM (1988). Retinoic acid and thyroid hormone induce gene expression through a common responsive element. Nature 336, 262-265. [PubMed: 2848197]

Vasios G, Gold JH, Petkovich M, Chambon P, and Gudas LJ (1989). A retinoic acid-responsive element is present in the S-flanking region of the laminin Bl gene. Proc. Natl. Acad. Sci. USA 86, 9099-9103. [PubMed: 2556699]

Weinberger C, and Bradley DJ (1990). Gene regulation by receptors binding lipid-soluble substances. Annu. Rev. Physiol 52, 823-840. [PubMed: 2158771]

Wondisford FE, Farr EA, Radovick S, Steinfelder HJ, Moates JM, McClaskey JH, and Weintraub BD (1989). Thyroid hormone inhibition of human thyrotropin $\beta$-subunit gene expression is mediated by a cis-acting element located in the first exon. J. Biol. Chem 264, 14601-14604. [PubMed: 2768233]

Yamamoto KR (1985). Steroid receptor regulated transcription of specific genes and gene networks. Annu. Rev. Genet 19, 209-252. [PubMed: 3909942]

Zilz ND, Murray MB, and Towle HC (1990). Identification of multiple thyroid hormone response elements located far upstream of the rat St4 promoter. J. Biol. Chem 265, 8136-8143. [PubMed: 2159469] 


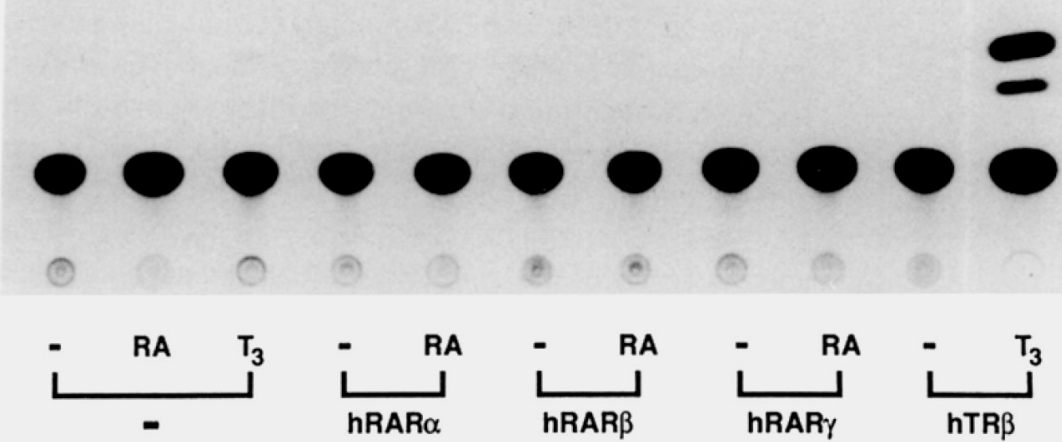

Figure 1. TR-Specific Transactivation of a TRE-CAT

The reporter plasmid paTRE.Al0-CAT encodes a portion of the rat cardiac MHC a subunit gene, which confers $\mathrm{T}_{3}$ responsiveness onto a heterologous promoter to drive expression of a chloramphenicol acetyltransferase (CAT) gene (Izumo and Mahdavi. 1988). Together with an internal control plasmid (pRAS- $\beta$ GAL), the reporter plasmid was cotransfected with an expression plasmid coding for the firefly luciferase (-), the human RARa (hRARa), $-\beta$ (hRAR $\beta$ ). or $-\gamma$ (hRAR $\gamma$ ), or the human TR $\beta$ (hTR $\beta$ ) into CV-1 cells. Subsequently, cognate hormones were added to the culture media at $1 \mu \mathrm{M} \mathrm{RA}, 100 \mathrm{nM} \mathrm{T}_{3}$, or solvent ethanol (-). Thirty-six hours after adding the ligands, cellular extracts were prepared and assayed for the CAT enzyme activity after monitoring the $\beta$-galactosidase activity to correct variation of the transfection efficiency. 
a)

TREP

MHC-L

MHC-S

MHCD

b)

MHC-N

M1

M2

M3

c)

malic enzyme

MLV-LTR

rGH21

BRARE

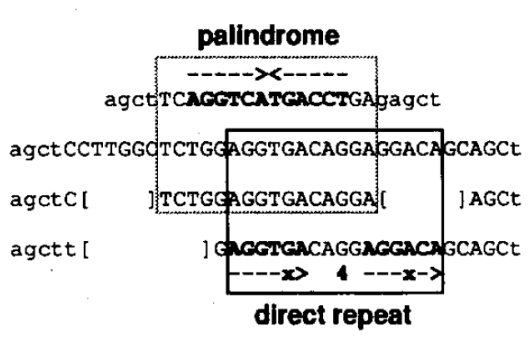

agCTGGAGGTEACAGGAGGACAGCAagCt

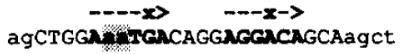

$-x x-x>---x->$

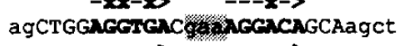

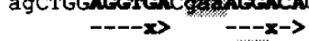

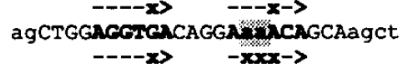

$---x>\quad-x \times x->$

agCT GeCGITMGGGGACGRCAGTaagct $x---x>4---x->$

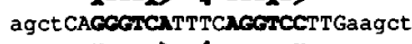

$x--->$ । $-----x$

agct MCGMAGATCACGMAGTaget

$----x)(---x)$

agCt $t$ AAGCGMCACCGAAMOMTCACTCGCATagCt

$x-x \rightarrow->5--x \rightarrow->$
Fold induction
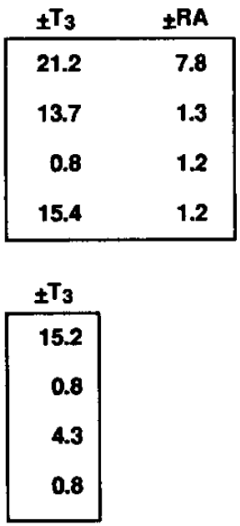

\begin{tabular}{|rr|}
\hline \multicolumn{1}{|c}{ $\pm T_{3}$} & $\pm R A$ \\
\hline 15.4 & 1.8 \\
29.5 & 1.8 \\
0.9 & 0.9 \\
0.5 & 14.0 \\
\hline
\end{tabular}

Figure 2. Structure and Responsiveness of Target HREs for $\mathbf{T}_{\mathbf{3}}$ and RA

Target HREs for the TR and RAR were synthesized as double-stranded oligonucleotides with an overhanging tetranucleotide (5'-agct-3') at both ends. A single copy of these oligonucleotides was cloned at the unique Hindlll site present in a basal promoter CAT construct, $\triangle \mathrm{SV}$-CAT (see Experimental Procedures). Capitalized portions in the nucleotide sequences correspond to those found in the natural promoters except TREp and rGH21, which are synthetic. Bold letters and arrows indicate the AGGTCA motif and " $\mathrm{X}$ " denotes a nucleotide substitution from this motif. Numbers between the arrows are the size of the spacer and those in columns represent fold inductions of the CAT enzyme activity stimulated by the hormones in either the TR8groducing $\left( \pm \mathrm{T}_{3}\right.$ at $\left.100 \mathrm{nM}\right)$ or RARa-producing $( \pm \mathrm{RA}$ at $1 \mu \mathrm{M}) \mathrm{CV}-1$ cells. Inductions observed on the basal construct $\triangle \mathrm{SV}-\mathrm{CAT}$ by $\mathrm{T}_{3}$ and RA are 0.8 and 14 -fold, respectively.

(a) TREp is an optimized palindromic rGH TRE (Glass et al., 1988). which stands also as an efficient RARE (Umesono et al., 1988). MHC-L encodes a TRE localized at positions between -154 and -122 from a transcription start site in the MHC gene promoter (shown as an antisense; Glass et al., 1989). MHC-S and -D contain deletion(s) (indicated by brackets) from the MHC-L.

(b) MHC-N encodes a core sequence of the wild-type MHC TRE, whereas M1 through M3 contain specific nucleotide substitutions (shaded letters and " $\mathrm{X}$ " in the arrow if they are located in the AGGTCA motif).

(c) Malic enzyme TRE corresponds to -281 to -261 from a transcription start site (Petty et al., 1990). A TRE found in the MLV LTR was taken from Sap et al. (1989) and rGH21 is a mutant of the rGH gene TRE (Brent et al., 1989a). $\beta$ RARE corresponds to 8RE2 reported in Sucov et al. (1990). 


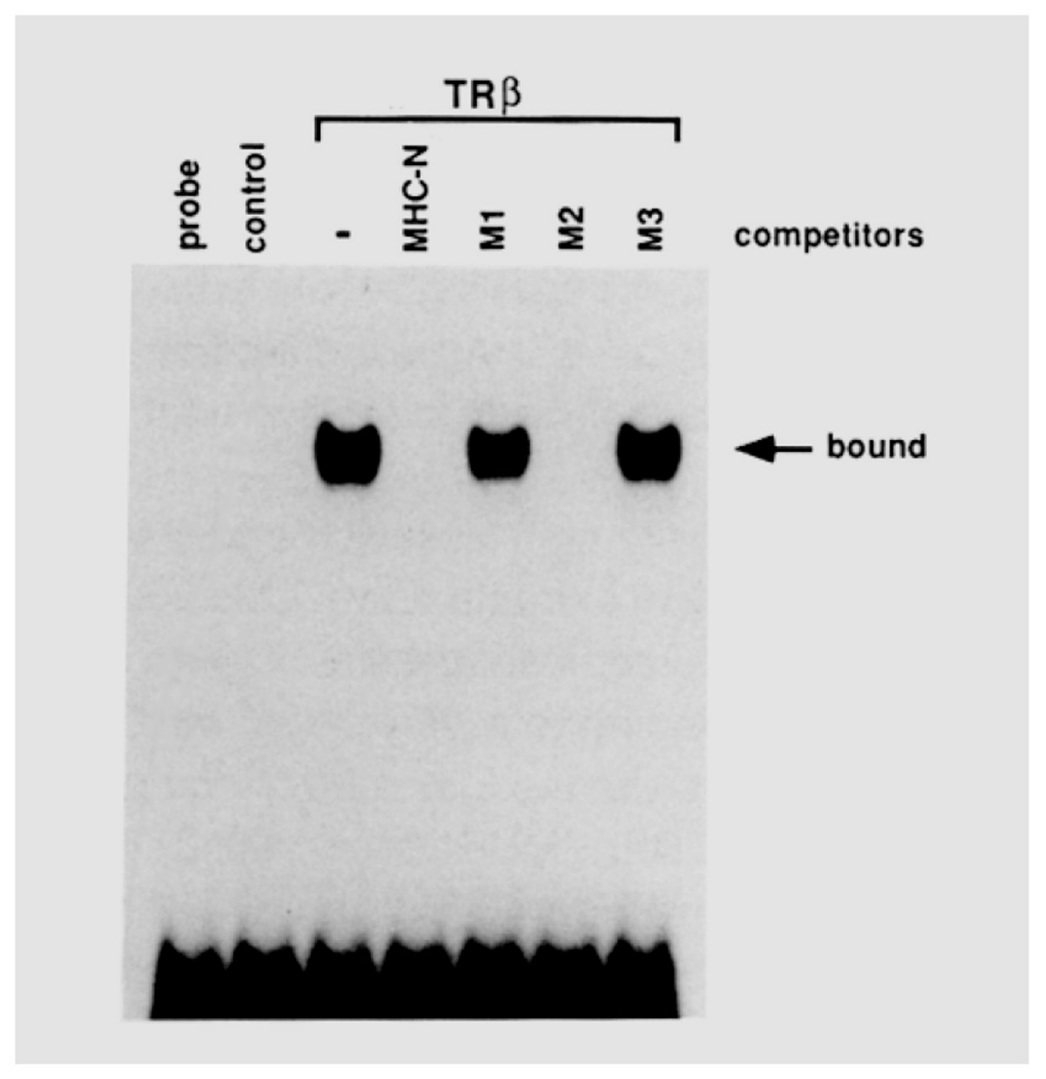

Figure 3. In Vitro DNA Binding of the TR $\beta$ Protein to MHC TRE Mutants

As a radiolabeled probe for the gel retardation DNA-binding assay, the MHC-N doublestranded oligonucleotides were labeled by a filling-in reaction with Klenow enzyme in the presence of $\left[a-{ }^{32} \mathrm{P}\right] \mathrm{dCTP}$. TR $\beta$ protein was overexpressed in COS cells by transfecting 20 $\mu \mathrm{g}$ of pCMX-TR $\beta$ plasmid. As a control, cell extracts were also prepared from mocktransfected $(20 \mu \mathrm{g}$ of pCMX-LUC) COS cells. Protein $(5 \mu \mathrm{g})$ of the mock- (control) or TR $\beta$ transfected cell extracts was incubated with the MHC-N probe, and the protein-DNA complex was resolved electrophoretically according to Damm et al. (1989). With the TR $\beta$ extracts, 50-fold excess amounts of cold oligonucleotides as indicated were added as a competitor for the TR $\beta$ binding to the MHC-N. 


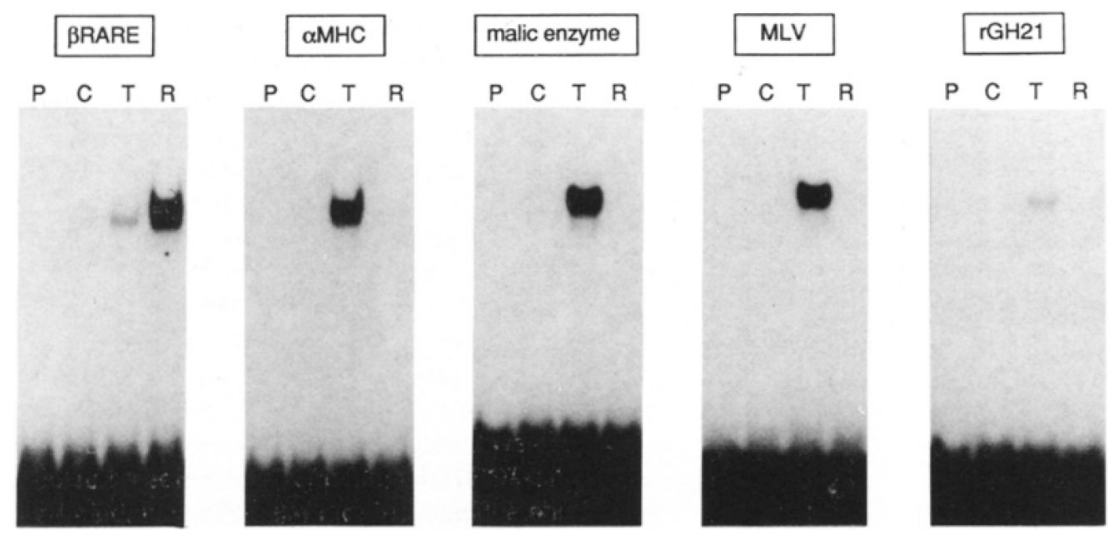

Figure 4. Mutually Exclusive HRE Binding by the TR $\beta$ and RARa Proteins The ${ }^{32} \mathrm{P}$-labeled oligonucleotides at the top (listed in Figure 2, aMHC corresponds to MHC$\mathrm{N}$ oligonucleotides) were used as a probe for gel retardation DNA-binding assays with $5 \mu \mathrm{g}$ of protein of either control (C), TR $\beta$ (T), or RARa (R) COS cell extracts. These extracts were prepared aftertransfecting COScells with $20 \mu \mathrm{g}$ of pCMX-LUC, pCMX-hTR $\beta$, or pCMX-hRARa expression plasmids, respectively. 
a)

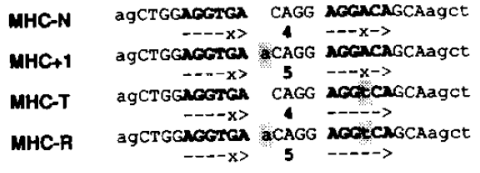

b)

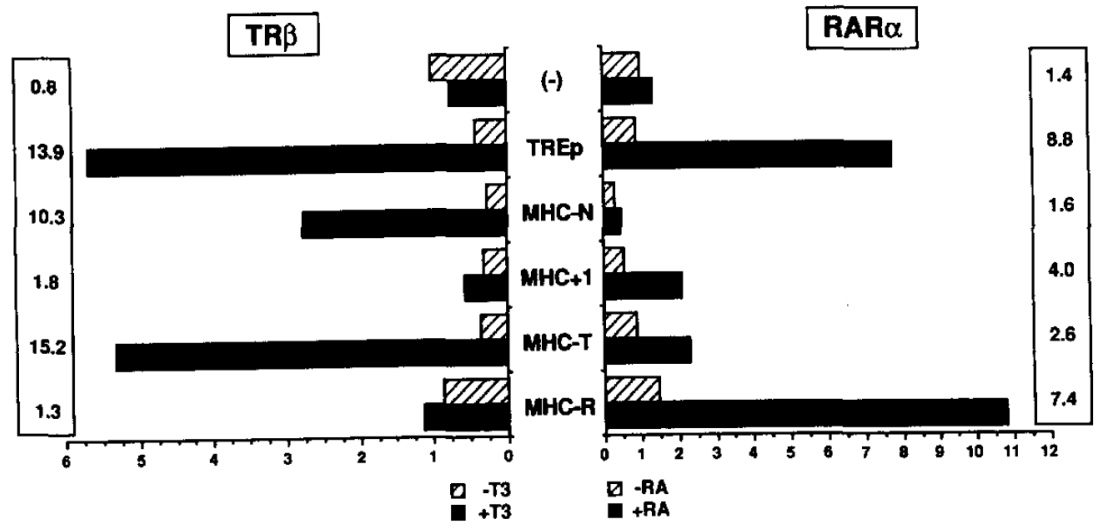

Figure 5. Conversion of the MHC TRE into an RARE

(a) Four different oligonucleotides were synthesized encoding the wild-type MHC TRE (MHC-N), an insertion mutant in the spacer region $(\mathrm{MHC}+\mathrm{l})$, a half-site mutant (MHC-T), and a double mutant carrying both the $\mathrm{MHC}+\mathrm{l}$ and $\mathrm{MHC}-\mathrm{T}$ mutations (MHC-R). A single copy of these oligonucleotides was placed in the basal reporter construct $\triangle \mathrm{SV}$-CAT (-), giving rise to a set of CAT reporter plasmids together with one encoding TREp (see Figure 2).

(b) Transactivation assays by $\mathrm{T}_{3}$ and RA. CV-1 cells were transfected with one of these reporters along with an expression plasmid coding for the TR $\beta$ or RARa. After addition of the hormones (RA, $1 \mu \mathrm{M} ; \mathrm{T}_{3}, 100 \mathrm{nM}$ ), the cell extracts were assayed for the CAT activity by measuringthe control $\beta$-galactosidase activity produced by cotransfected pRAS- $\beta$ GAL. Numbers in the columns indicate a fold induction of the CAT activity by the hormone. 
a) TR $\beta$ / MHC-TRE
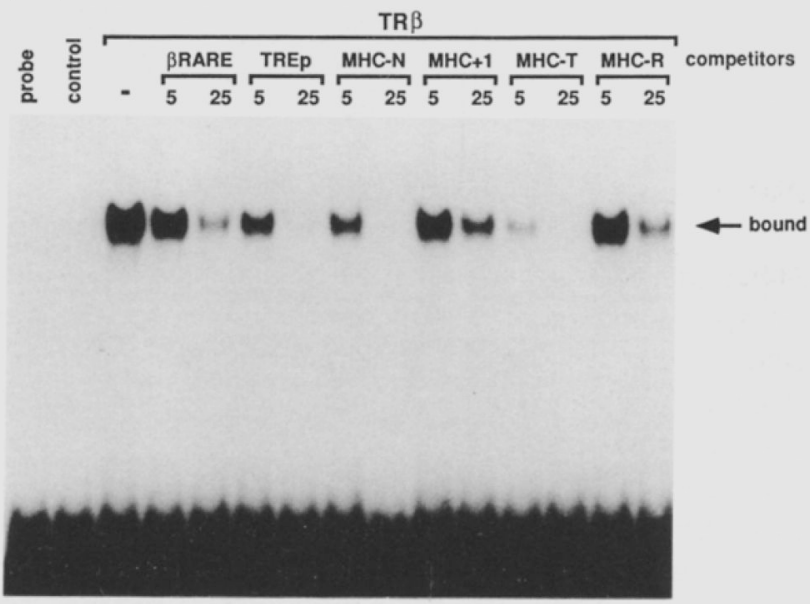

b) RAR $\alpha$ / $\beta$ RARE
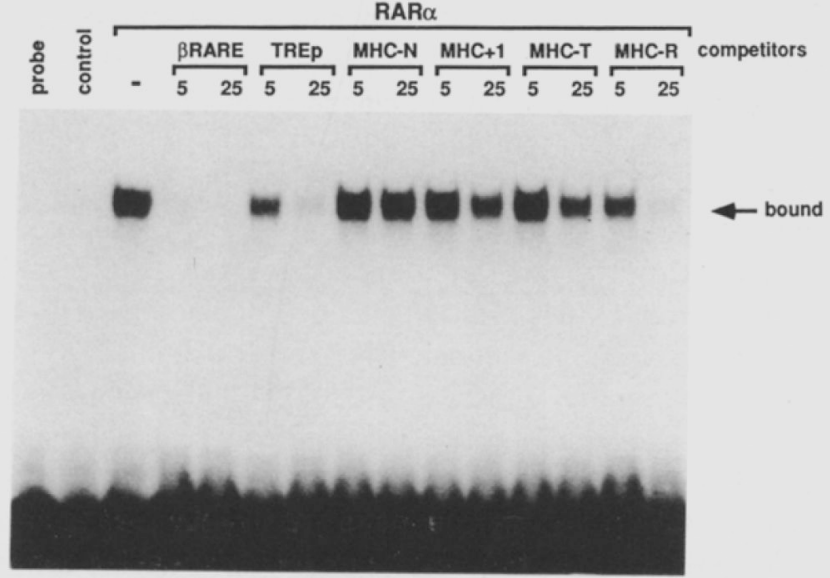

Figure 6. In Vitro DNA Binding of the TR $\beta$ and RARa to MHC TRE/RARE Mutants ${ }^{32} \mathrm{P}$-labeled MHC-N (a) or $\beta$ RARE (b) oligonucleotides were used as a probe for gel retardation DNA-binding assays with $5 \mu \mathrm{g}$ of protein of either control, TR $\beta$. or RARa cell extracts as in Figure 4. A minus sign indicates no competitor was included during the reaction. Otherwise, indicated oligonucleotides ( $\beta$ RARE, TREp, MHC-N, MHC+1, MHC-T, MHC-R) with either 5- or 25-fold molar excess to the probe were added to the binding reaction. 
a)

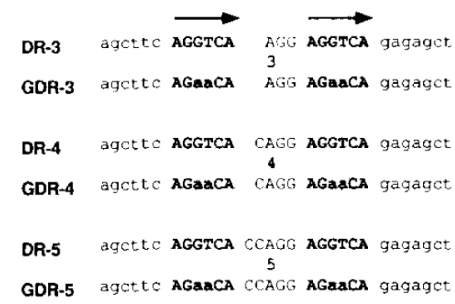

b) VDR

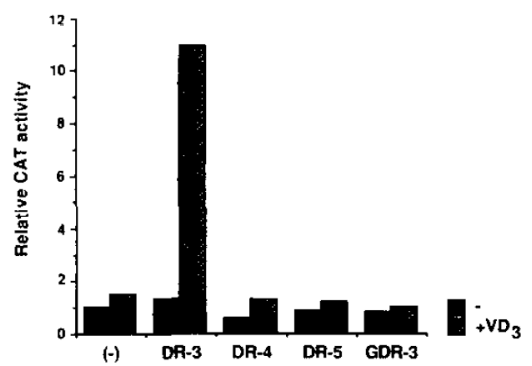

c) $\operatorname{TRB}$

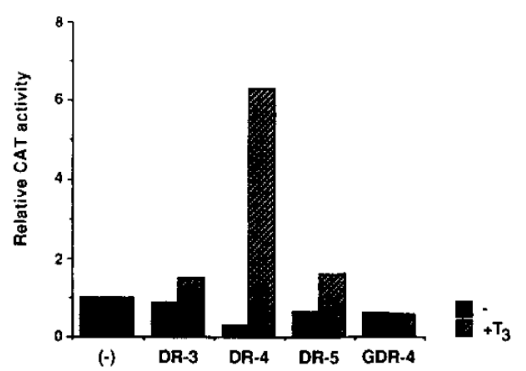

d) RAR $\alpha$

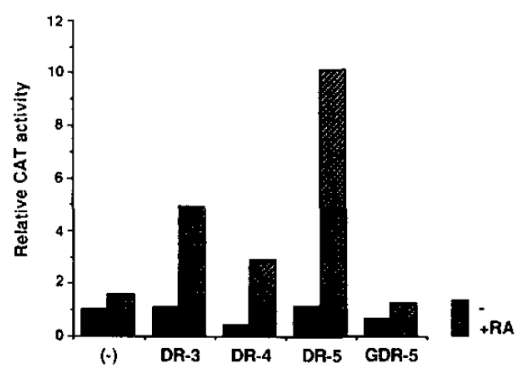

Figure 7. Selecttve Transactivation of Synthetic Direct Repeat HREs by $V_{3}, T_{3}$. and RA (a) Nucleotide sequences of the oligonucleo-tides encoding synthetic direct repeat HREs. DR-3, -4 , and -5 code for a perfect tandem repeat of AGGTCA hextamers (indicated by arrows) separated by 3, 4, and 5 nucleotides, respectively. GDR-3, -4 , and -5 are identical to the DR oligonucleotides except that the half-site sequence was changed to AG $\underline{A C A}, \mathrm{a}$ GRE half-site.

(b-d) A single copy of DR or GDR oligonucleo-tides was cloned at the unique Hindlll site present in the basal promoter CAT construct $\triangle$ SVCAT, giving rise to DR-3-CAT, DR-CCAT, DR-SCAT. GDR-3CAT. GDR-4CAT, and GDR-5CAT reporters. One mtcrogram of the indicated reporters (a minus sign corresponds to ASV-CAT) was cotransfected along with $0.5 \mu \mathrm{g}$ of an expression plasmid for VDR (b), TR $\beta$ (c). or RARa (d) to CV-1 cells. After 36 hr of incubation with the cognate ligands $\left(\mathrm{VD}_{3}\right.$, and $\left.\mathrm{T}_{3} ; 100 \mathrm{nM} ; \mathrm{RA}, 1 \mu \mathrm{M}\right)$, the cells were harvested for the CAT assay after normalization with $\beta$-galactosidase activity produced from the cotransfected control reporter pRAS- $\beta$ GAL. The CAT activity obtained through $\Delta \mathrm{SV}$ CAT in the absence of the ligand was taken as 1 for each of the receotors. 
a)

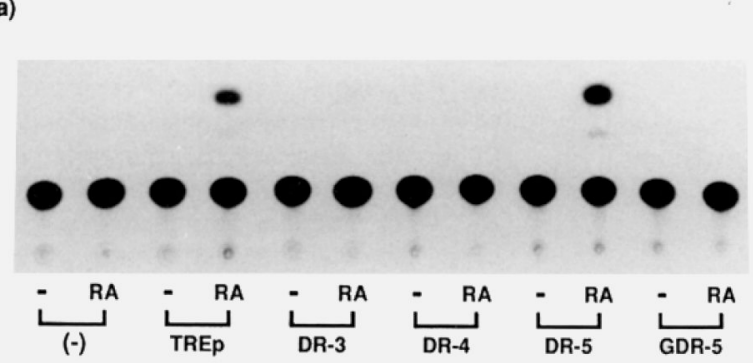

b)

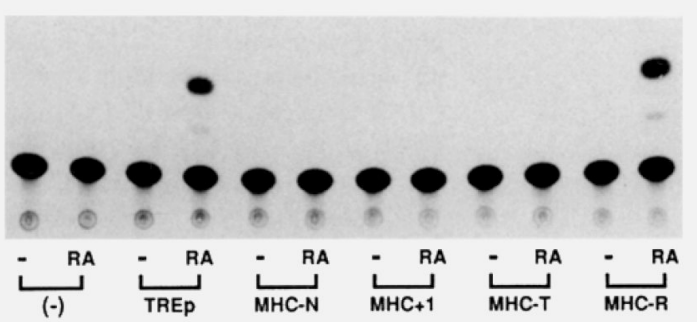

c) F9 / BRARE

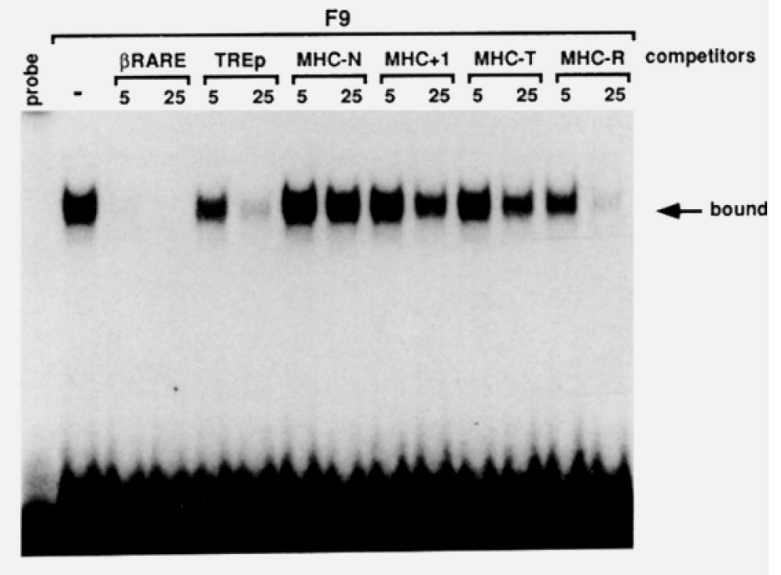

Figure 8. RAeDependent Transactivation in F9 Teratocarcinoma Cells

( $\mathrm{a}$ and b) Indicated reporter CAT plasmids $(2 \mu \mathrm{g})$ were transfected into F9 teratocarcinoma cells with the control pRA- $\beta$ GAL plasmid. After $24 \mathrm{hr}$ of incubation with RA at $1 \mu \mathrm{M}$, the cells were harvested and CAT activities were analyzed.

(c) F9 cells were kept undifferentiated in the media and whole-cell extracts were prepared with $0.4 \mathrm{M}$ KCI. We have confirmed that the F9 cells express RARa and RAR $\gamma$, but not RAR $\beta$ mRNAs (A. Kakizuka and R. M. E., unpublished data). Ten micrograms of the F9 proteins was incubated with $40 \mathrm{fmol}$ of ${ }^{32} \mathrm{P}$-labeled f3RARE oligonucleotide for proteinDNA binding assays. When included, either a 5- or 25-fold molar excess of unlabeled competitor oligonucleotides ( $\beta$ RARE, TREp, MHC-N, MHC+i, MHC-T, or MHC-R) to the probe was added to the reaction mixture. 


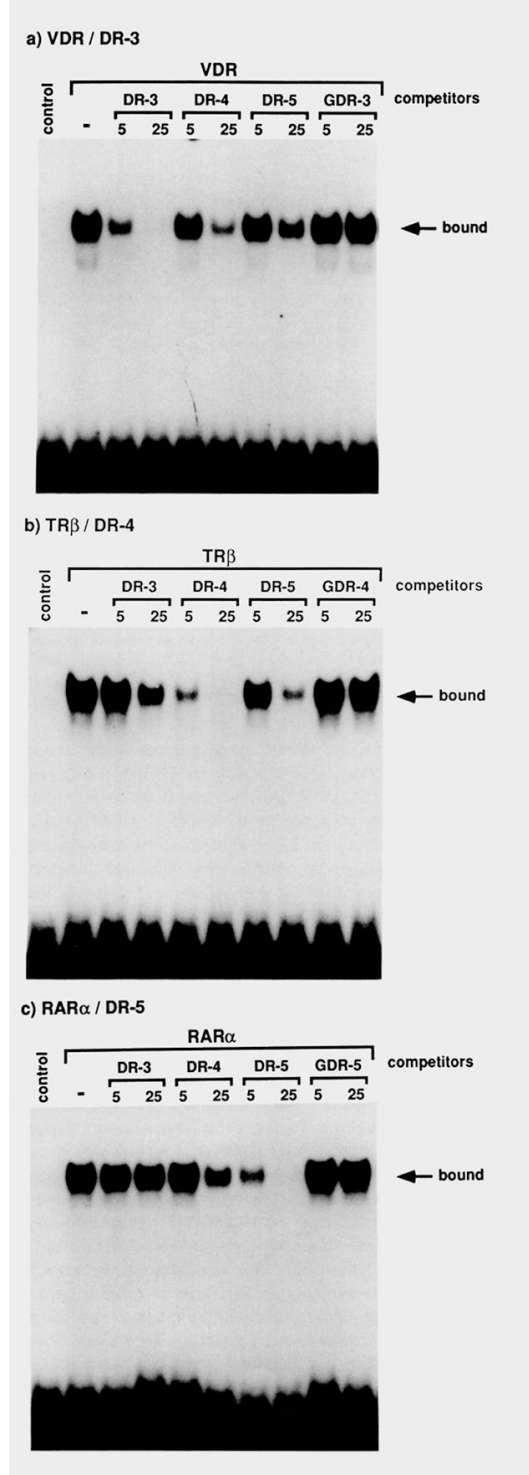

Figure 9. Specific DNA Binding of VDR, TR $\beta$, and RARa Proteins to the Direct Repeat HREs $\left[a-{ }^{32}\right.$ P]dCTP-labeled DR-3 (a), DR-4 (b), or DR-5 (c) oligonucleotides were used as a probe for gel retardation DNA-binding assays with $5 \mu \mathrm{g}$ of protein of either control, VDR-, TR $\beta$-, or RARa-transfected COS cell extracts as in Figure 4. A minus sign indicates no competitor was included during the binding reaction. Otherwise, indicatedoligonucle tides with either 5- or 25-fold molar excess to the probe were added to the reaction mixtures as a competitor. 


\begin{tabular}{|c|c|c|c|c|c|c|c|}
\hline \multirow{2}{*}{$\begin{array}{l}\text { a) VDRE } \\
\text { DR-3 }\end{array}$} & \multicolumn{3}{|c|}{ (ștrong/active) } & \multicolumn{4}{|c|}{ (weak/inactive) } \\
\hline & AGGTCA & $\mathrm{AGG}$ & AGGTCA & & & & \\
\hline $\begin{array}{l}\text { rOST } \\
\text { hOST } \\
\text { mSPP-1 }\end{array}$ & $\begin{array}{l}\text { GGGTGA } \\
\text { GGGTGA } \\
\text { GGTTCA }\end{array}$ & $\begin{array}{l}\text { ATG } \\
\text { ACG } \\
\text { CGA }\end{array}$ & $\begin{array}{l}\text { AGGACA } \\
\text { GGGGCA } \\
\text { GGTTCA }\end{array}$ & mLamB1 & AGGTGA & GCT & AGGT'PA \\
\hline b) TRE & & trong/a & ctive) & & (weak/i & nactive) & \\
\hline $\begin{array}{l}\text { DR-4 } \\
\text { MHC-T }\end{array}$ & $\begin{array}{l}\text { AGGTCA } \\
\text { AGGTGA }\end{array}$ & $\begin{array}{l}\text { CAGG } \\
\text { CAGG }\end{array}$ & $\begin{array}{l}\text { AGGTCA } \\
\text { AGGTCA }\end{array}$ & $\begin{array}{l}\text { DR-4M } \\
\text { rGH21 }\end{array}$ & $\begin{array}{l}\text { TGGTCA } \\
\text { AGGTAA }\end{array}$ & $\begin{array}{l}\text { CAGG } \\
\text { GATC }\end{array}$ & $\begin{array}{l}\text { TGGTCA } \\
\text { AGGTAA }\end{array}$ \\
\hline $\begin{array}{l}\text { rMHC } \\
\text { hMHC } \\
\text { rME } \\
\text { MLV } \\
\text { rS14 }\end{array}$ & $\begin{array}{l}\text { AGGTGA } \\
\text { AGGTGA } \\
\text { GGGTTA } \\
\text { GGGTCA } \\
\text { GGGCCA }\end{array}$ & $\begin{array}{l}\text { CAGG } \\
\text { CAGG } \\
\text { GGGG } \\
\text { TTTC } \\
\text { GCTG }\end{array}$ & $\begin{array}{l}\text { AGGACA } \\
\text { AGGACA } \\
\text { AGGACA } \\
\text { AGGTCC } \\
\text { AGGTTA }\end{array}$ & $\begin{array}{l}\text { MACTIN } \\
\text { BRARE-1 }\end{array}$ & $\begin{array}{l}\text { GGGTGA } \\
\text { GGTTCA }\end{array}$ & $\begin{array}{l}\text { ATGG } \\
\text { CCGA }\end{array}$ & $\begin{array}{l}\text { GGGTGA } \\
\text { AGTTCA }\end{array}$ \\
\hline c) RARE & (str & ong/ac: & (ive) & & (weakji & nactive) & \\
\hline $\begin{array}{l}\text { DR-5 } \\
\text { MHC-R }\end{array}$ & $\begin{array}{l}\text { AGGTCA } \\
\text { AGGTGA }\end{array}$ & $\begin{array}{l}\text { CCAGG } \\
\text { ACAGG }\end{array}$ & $\begin{array}{l}\text { AGGTCA } \\
\text { AGGTCA }\end{array}$ & $M H C+1$ & AGGTGA & ACAGG & AGGACA \\
\hline $\begin{array}{l}\text { mRAR } \beta \\
\text { hRAR } \beta \\
\text { mCP-H } \\
\text { hADH3 }\end{array}$ & $\begin{array}{l}\text { GGTTCA } \\
\text { GGTTCA } \\
\text { AGGTCA } \\
\text { GGGTCA }\end{array}$ & $\begin{array}{l}\text { CCGAA } \\
\text { CCGAA. } \\
\text { CTGAC } \\
\text { TTCAG }\end{array}$ & $\begin{array}{l}\text { AGTTCA } \\
\text { AGTTCA } \\
\text { AGGGCA } \\
\text { AGTTCA }\end{array}$ & hMCK & AGGTGA & GGCTG & CGGTGA \\
\hline
\end{tabular}

Figure 10. Sequence Comparison of the Direct Repeat HREs

(a) rOST, the rat osteocalcin gene promoter ( -455 to -441 from a transcription start site; Demay et al., 1990); hOST, the human osteocalcin gene promoter ( -499 to -485 ; Ozono et al., 1991); mSPP-1, the mouse Sppllosteopontin promoter (-757 to -743; Noda et al., 1990). We confirmed that this spp-l VDREconfers vitamin $\mathrm{D}_{3}$ response io the basal reporter $\Delta \mathrm{SV}$ CAT, but a similar motif found in the 3' end of the mouse laminin B1 RARE (mLamB1, -448 to -433 shown as an antisense after Vasios et al., 1989) does not function as a VDRE (data not shown).

(b) rMHC, the rat cardiac MHC a gene promoter (-149 to -134; Izumo and Mahdavi, 1988; Glass et al., 1989); hMHC, the human MHC promoter (-158 to -143 ; Flink and Morkin, 1990); rME, the rat malic enzyme gene promoter (-276 to -261; Petty et al., 1990); MLV, positions between 334 and 350 shown as an antisense (Sap et al., 1989); rS14, the rat S14 gene TRE (personal communication from How ard C. Towle). The oligonucleotides encoding DR-4M (A toT change in the 5' end of each of the half-sites in DR-4) or the mouse skeletat actin gene promoter upstream sequence (mACTIN, -597 to -582 from a transcription start site; Hu et al., 1986) failed to confer $\mathrm{T}_{3}$ response to the basal reporter (data not shown). For rGH21 and $\beta$ RARE-1, see text.

(c) mRAR $\beta$, the mouse RAR type $\beta$ gene promoter (Sucov et al., 1990); hRAR $\beta$, the human RAR type $\beta$ gene promoter ( -52 to -37 ; de The et al., 1990); mCP-H, the mouse complement factor $\mathrm{H}$ gene promoter (-143 to -127; Muiioz-Cdnoves et al., 1990); hADH3, the human alcohol dehydrogenase gene promoter ( -300 to -284 shown as an antisense; Duester et al., 1991). Oligonucleotides coding for a motif found in $2.4 \mathrm{~kb}$ upstream of the human muscle creatine kinase gene (hMCK; Trask et al., 1988) did not confer RA response (data not shown). 